\title{
Towards Good Governance on Dual-Use Biotechnology for Global Sustainable Development
}

\author{
Yang Xue ${ }^{1,2}$, Hanzhi $\mathrm{Yu}^{3, *}$ and Geng Qin $^{3}$ (D) \\ 1 Law School, Tianjin University, Tianjin 300072, China; xueyang@tju.edu.cn \\ 2 Center for Biosafety Research and Strategy, Tianjin University, Tianjin 300072, China \\ 3 School of Public Affairs, Zhejiang University, Hangzhou 310058, China; libertas@zju.edu.cn \\ * Correspondence: yuhz@zju.edu.cn
}

Citation: Xue, Y.; Yu, H.; Qin, G.

Towards Good Governance on

Dual-Use Biotechnology for Global Sustainable Development.

Sustainability 2021, 13, 14056. https:/ /

doi.org/10.3390/su132414056

Academic Editors: Oran Young and Changhyun Roh

Received: 8 October 2021

Accepted: 17 December 2021

Published: 20 December 2021

Publisher's Note: MDPI stays neutral with regard to jurisdictional claims in published maps and institutional affiliations.

Copyright: (c) 2021 by the authors. Licensee MDPI, Basel, Switzerland. This article is an open access article distributed under the terms and conditions of the Creative Commons Attribution (CC BY) license (https:/ / creativecommons.org/licenses/by/ $4.0 /)$.

\begin{abstract}
Dual-use biotechnology faces the risks of availability, novel biological agents, knowledge, normative, and other dual-use risks. If left unchecked, these may destroy human living conditions and social order. Despite the benefits of dual-use technology, good governance is needed to mitigate its risks. The predicaments facing all governments in managing the dual-use risks of biotechnology deserve special attention. On the one hand, the information asymmetry risk of dual-use biotechnology prevents the traditional self-governance model in the field of biotechnology from playing its role. On the other hand, top-down public regulation often lags behind technological iteration due to the difficulty of predicting the human-made risks of dual-use biotechnology. Therefore, we argue that governance of the dual-use risks of biotechnology should avoid the traditional bottom-up or top-down modes. We suggest the governance for dual-use biotechnology could be improved if the four-stage experimentalist governance model is followed. The first stage is to achieve consensus on a broad governance framework with open-ended principles. The second stage is for countries to take action based on local conditions and the open-ended framework. The third stage is to establish a dynamic consultation mechanism for transnational information sharing and action review. The fourth and final stage is to evaluate and revise the global governance framework.
\end{abstract}

Keywords: risks of dual-use biotechnology; double predicament; experimentalist governance model

New dual-use biotechnology, represented by gene editing, synthetic biology, and gene driving, has brought great benefits to human health and welfare, but may also be used for the development of biological weapons or bioterrorism. The international community recognizes the potential social and economic benefits of dual-use biotechnology, but it is difficult to prevent this technology from being misused or abused.

What are the risks of dual-use biotechnology? What are the difficulties and challenges in the current risk management system and can they be resolved? This paper explores these questions to deepen our understanding of the risks of dual-use biotechnology and countermeasures so that such technology can benefit sustainable development of humanity.

\section{Dual-Use Risks of Biotechnology and Countermeasures}

\subsection{Definition of "Dual-Use Biotechnology"}

In the military field, "dual-use" biotechnology refers to both civilian and military technology [1]. In the civilian field, it refers to a legitimate scientific purpose that yields information or technologies that may be misused to pose a threat to public health or other aspects of national security [2]. Dual-use biotechnology has benefits (such as promoting scientific progress or improving public health) but also has the potential for malicious abuse or misuse (such as bioterrorism). At present, internationally recognized dual-use biotechnology consists of technology used for acquiring new types of biological or molecular materials (combinatorial chemistry and high throughput screening, DNA shuffling, and directed evolution), directed design technologies (protein engineering, virus genome synthesis, standardization in synthetic biology), technologies for manipulating biological 
systems (development of psychoactive drugs, synthesis of peptide bioregulators, immune regulation, personal genomics, RNA interference, transcranial magnetic stimulation), and technologies for the packaging and delivery (chemical micro-processing equipment, gene therapy, aerosol vaccine). Tucker lists three characteristics of dual-use: (1) its technical attributes, including availability, abuse susceptibility and potential harm caused by abuse; (2) its controllability, including concretization (the materialization of technology), maturity, convergence, development speed and international diffusion; and (3) the reducibility to the state, institutional, individual, product and knowledge levels [3]. However, due to its ubiquity, it is difficult to manage the risks of all dual-use biotechnologies. Therefore, NSABB has adopted a strategy of determining a limited scope of knowledge, products or technologies produced by life science research that is most likely to be misused to threaten national biosafety. This part of research is referred to as "dual-use research concerns", and encompasses 15 key biological agents or toxins and seven types of dual-use research [4].

\subsection{Four Types of Risks of Dual-Use Biotechnology}

Tucker [3] categorized four abusable risks of dual-use biotechnology in his bookInnovation, Dual-use and Safety: Managing the Risks of Emerging Biological and Chemical Technologies. These risks are availability, novel biological agent, knowledge, and normative.

\subsubsection{Accessibility Risks}

Accessibility is the difficulty in obtaining dual-use biotechnology. It is the first step of the intentional misuse of biotechnology, including obtaining hardware, software, and intangible information that can be applied to such technology for non-state actors to carry out bioterrorism activities. In the field of dual-use biotechnology, non-state actors can include ethnic separatists, transnational criminal organizations, terrorist organizations, cults, biohackers, and others who engage in covert behavior, have more freedom to conduct research, and are more difficult to supervise than state actors. At the Eighth Review Conference of the Convention on the Prohibition of Biological Weapons, the U.S. government announced that bioterrorism plots had been foiled by Kenya and Morocco. In addition, more than 15 criminal cases in the past ten years have involved the use of biological weapons in the U.S. There is therefore increasing concern over non-state actors using dual-use biotechnology to carry out bioterrorist attacks [5].

There are three accessibility risks of dual-use biotechnology. One is the disclosure of key technical information, such as key gene sequences of highly pathogenic pathogens that can be easily obtained from academic conferences, journals and public databases. In 2011, scientists from the United States and the Netherlands published academic papers on the transmission ability of highly pathogenic H5N1 influenza virus in mammalian cells, in which the methods of modifying the virus so as to enhance its transmission ability were made public [6]. This event that triggered global concern about the dual-use risk of biotechnology [7]. In addition, it is now easier than ever to obtain key experimental materials. In light of the industrialization of biotechnology, biotechnology enterprises can provide technical services and related reagents, including the detailed steps of entire experiments. Anyone can readily order laboratory equipment, consumables and substitutes online, and each year these become less expensive, so it is not difficult to set up a simple biology laboratory [8]. Finally, there are more ways than ever to obtain technology. More methods of communication have emerged outside of traditional channels in recent years, including the International Genetic Engineering Machine Competition (iGEM) and other international biology academic competitions, as well as online forums such as DIY biology.

\subsubsection{Novel Biological Agent Risks}

Novel agent risks are the identification or development of new biological agents or toxins with the assistance of dual-use biotechnology. These risks also encompass "gain of function" research into pathogenic viruses, including combinatorial chemistry, high-throughput screening, DNA shuffling, directed evolution or protein engineering [3]. 
For example, gene editing technology, represented by CRISPER-Cas9, can greatly change the biological traits of pathogens, animals and plants, and even humans in a short time. Gene synthesis technology can artificially resurrect extinct pathogenic viruses, so that bacteria and viruses with higher pathogenicity can be synthesized, the receptors of which may have unprecedented biological characteristics [9]. In 2018, Canadian scientists obtained overlapping gene fragments through mail order, splicing them to synthesize a horse pox virus which was similar to the smallpox virus [10]. These artificially synthesized viruses are more capable of infecting, spreading, killing, and escaping than natural viruses, so it is more difficult to trace their origins. In addition, RNA interference and personal genomics, realized by gene driving technology, may not only be used as crowd-specific weapons to reduce human reproductive capacity and change the number of specific human populations, but also be used to manufacture insect weapons for transnational transmission of dengue fever, Zika, and other diseases.

\subsubsection{Knowledge Risks}

Knowledge risks reflect the fact that as human understanding of life science at the molecular and system levels deepens, research may be abused to attack knowledge loopholes. For example, the study of immune regulation is intended to improve human immunity to infectious diseases. However, a specific pathogen can be modified through engineering to bypass acquired or innate immune barriers, while importing immunosuppressants and biological weapons into specific populations to achieve the double purpose of reducing immunity and causing disease [11]. In addition, dual-use biotechnology can be used to subvert traditional weapons and equipment and attack the weaknesses in national defense military facilities. For example, at the Eighth Review Conference of the States Parties to the United Nations Biological Weapons Convention (BWC), the U.S. military revealed that it had been able to use gene synthesis technology to produce material damage factors aimed at non-living substances. Such non-traditional weapons can attack "rubber and metal parts, fuel, food and equipment", accelerate the corrosion of rubber and metal parts of weapons, and destroy military fuel, supplies, instruments and equipment [5]. In theory, gene drive technology could be used to reduce human reproductive capacity and alter the size of specific human populations [12]. In recent years, biological scientists in the United States, Europe, and other developed countries have repeatedly called for appropriate biosafety precautions to minimize the uncertain risks of gene drive technologies to the environment, plants and animals, and human health [13].

\subsubsection{Normative Risks}

Normative risks use dual-use biotechnology to destroy the framework of international biosafety governance conventions, including the Biological Weapons Convention (BWC). For example, new neuropeptide biological agents that can influence and manipulate specific wills or emotions have been manufactured. These agents can induce visual or auditory hallucinations, and cause disability or even extreme hysteria during interrogation, violating the human rights of detainees and breaking international humanitarian law. Normative risks also concern the self-regulation of scientists. In 2018, He Jiankui of China's Southern University of Science and Technology created the world's first gene-edited infant, in violation of the international regulation that "gene-edited early human embryos (within 14 days of age) and germ cells should not be used for pregnancy." Normative risks also involve the application of dual-use biotechnology to existing international ethical principles and norms. He Jiankui violated the Helsinki Declaration, the International Ethical Guidelines for Biomedical Research Involving Human Subjects, and other international ethics, and principles and common views designed to "respect and protect subjects, maximize subject benefit and avoid subject injury as much as possible" [14]. 


\subsection{National Responses to Dual-Use Risks of Biotechnology}

From the perspective of global practice and international experience, the rules of governance towards dual-use risks of biotechnology consist of hard and soft laws. "Hard laws" are conventions, laws and regulations that are enforced using national coercive power. "Soft laws" are democratic, open, universal and normative rules formulated and recognized through extensive participation and joint consultation of all social parties, including codes of conduct and professional self-discipline. Hard and soft rules are not mutually exclusive. For example, the effectiveness of voluntary standards and guidelines can be strengthened through the enforcement of criminal law or tort law so as to punish harm caused by accidental or intentional abuse [15].

By the end of the 20th century, all countries had begun to pay attention to the four risks caused by dual-use biotechnology. In "Biotechnology, Weapons, and Humanity" (1999), the British Medical Association, for the first time in its history, expressed concern about the malicious abuse of genetic engineering, biotechnology and other emerging technologies, and suggested that social supervision should be strengthened and moral standards be established within the sciences to prevent the exacerbation of potential risks. In 2002, the Chinese government promulgated the "Regulations on Export Control of Dual-use Biological Products and Related Equipment and Technologies" to restrict the export of dual-use biological products and related equipment and technologies, to prevent them from being used to manufacture biological weapons [16]. In 2003, the National Academy of Sciences of the United States released a report, "Biotechnology Research in the Era of Terrorism" (the Fink Report), a pioneering document of the research into national security risks in the field of life science. The Fink Report identified seven types of biological experiments with dual-use risks, including microbiology and molecular biology experiments, which require safety inspections before project approval and funding [17]. To this end, the U.S. government set up a federal advisory committee under the National Biosafety Scientific Advisory Committee, which took charge of formulating policies and recommendations on dual-use research concerns (DURC) in life science research [2]. In 2004, the World Health Organization (WHO) announced that "every major new technology can be used not only for peaceful purposes, but also for hostile purposes. To tackle the common security challenges to all mankind, we should put the protection of biotechnology from being maliciously used above the security interests of all countries." In 2009, the European Union passed Regulation No. 428/2009, which listed the controlled goods subject to export restrictions and licenses, including dual-use biological materials and production equipment [18]. In the same year, the Federation of American Societies for Experimental Biology (FASEB) warned that "scientists who educate their research on potential dual-use shall pay more attention to taking necessary safety control measures" [19].

Since 2011, countries have paid more attention to the dual-use of biotechnology. After the research results on genetic modification of $\mathrm{H} 5 \mathrm{~N} 1$, the highly pathogenic avian influenza virus published in "Nature" in September 2011 triggered global controversy. The United States issued several regulatory policies concerning dual-use biotechnology, including the "Regulatory Policy on Dual-use Life Science Research of the U.S. Government" (2012) by the National Science Advisory Board for Biosecurity (NSABB), and the "Regulatory Policy of Dual-Purpose Research Institutions in Life Sciences of the U.S. Government" (2013) by Office of Science and Technology Policy (OSTP) [20]. In 2014, NSABB halted research on the Gain of Function of highly pathogenic avian influenza H5N1, severe acute respiratory syndrome (SARS) and middle east respiratory syndrome (MERS) viruses, and required all independent and federal research institutions to strictly abide by the "Dual-use Research of Concern" (DURC) from 24 September 2015, and established a special entity review body, the IRE. In 2015, the U.S. government established the "Institutional Regulatory Policy Concerning Dual-use Research in Life Sciences" [21]. In 2018, the U.S. government issued a "National Biodefense Strategy," and the National Academy of Sciences of the United States released the report "Biodefense in the Age of Synthetic Biology", which emphasized the imminent threat of synthetic biotechnology being used as a virus weapon 
for terrorist activities by biohackers [22]. In 2017, the Chinese government issued "Safety Management Measures for Biotechnology Research and Development" to impose special control measures for biotechnology research and development activities with high risks of causing serious diseases in humans or animals [23].

While strengthening supervision at home, some countries have begun to mitigate the dual-use risks of biotechnology on international governance platforms. In 2016, the United States and Britain submitted Working Papers No. 10, No. 14, and No. 17 to the General Assembly at the Eighth Review Conference of the States Parties to the BWC. Germany submitted 'Control Measures of Dual-use Materials' at the preparatory meeting, which emphasized that the dual-use of new biotechnology poses a greater threat of large-scale epidemics and bioterrorism [24-27]. The management of dual-use risks of biotechnology was put on the international agenda and became a hot topic in the field of international arms control. To counter the possible abuse and misuse of biotechnology, Working Paper No. 30, jointly submitted by the Chinese and Pakistani governments, proposed the formulation of a model code of conduct for biological scientists. It would be binding upon all biological scientists worldwide when conducting biological research. In this important meeting, the state parties agreed to "encourage the promotion of a culture of responsibility amongst relevant national professionals and the voluntary development, adoption and promulgation of codes of conduct" [28]. At the international level, UN Security Council Resolution 1540 has been passed as the principled framework, BWC has been adopted as the basic norm, and international export control standards have been established by informal associations, including Australia Group and similar organizations.

These conventions and standards have been adopted by the international community, and have been enshrined in laws, regulations and operational mechanisms, including China's "Regulations on Export Control of Dual-use Biological Products and Related Equipment and Technologies", the U.S. "Regulations on Export Administration", and Australia Group's "Guiding Principles on Export Control of Biosensitive Items".

\section{Double Predicament: Challenge of Governing Dual-Use Biotechnology}

Although the public now has a clearer understanding of the risks posed by dual-use biotechnology, and the international community has made great efforts to mitigate those risks, disputes over safety and ethics are still common in formulating governance policies worldwide. In the field of stem cell research, the Japanese government revised its "Treatment Policy for Specific Embryos" in 2019, which approved research on cultivating human organs for transplantation in animals by implanting human stem cells into animal embryos. At the same time, it lifted restrictions on the termination of humananimal chimeric embryos within 14 days and restrictions on implanting those embryos into surrogate uteruses [29]. Such embryos may develop into human-animal chimeras, raising ethical disputes over the blurring of boundaries between human and non-human animals. The cause of the governance disputes is that dual-use biotechnology entails human-made risks that are difficult to control in addition to information asymmetry risks. As a result, the traditional self-governance of the biotechnology industry is placed in a predicament where it is difficult for governance models to keep up with the development of emerging technologies.

\subsection{Predicament 1: The Information Asymmetry Risk of Dual-Use Biotechnology Keeps the Traditional Self-Governance Model in the Field of Biotechnology from Playing Its Role}

In contrast to the field of nuclear technology, in the biological sciences, the autonomy of stakeholders is important [30]. The biotechnology industry has a long tradition of self-governance, and there are many historical success stories. However, the information asymmetry risk of dual-use biotechnology has caused problems for the traditional model of industry self-governance.

Dual-use risks of biotechnology show obvious characteristics of information asymmetry. Since the research and development environment and application scenario of dual-use biotechnology are concealed, anonymous and opaque, the public may not be able to ac- 
quire enough information about the dual-use risk of biotechnology. The two hidden risks of information asymmetry are as follows. The research of scientists who have mastered dual-use biotechnology cannot be monitored effectively by the institutions with which they are affiliated. This could pose risks to national biosafety and public safety. Moreover, is difficult to supervise the application of dual-use biotechnology in the early stages of disease diagnosis and treatment, as well as drug research and development.

In response to these information asymmetry risks, professionals in the life sciences have always emphasized enhancing professional internal supervision mechanisms, but this may worsen information asymmetry. Researchers concerned with dual-use biotechnology acquire their professional skills in a closed environment, at scientific conferences, under the guidance of risk or ethics expert committees, and peer review of papers submitted for publication. All of these have formed an enclosed internal supervision mechanism for research, training and practice. These monitoring mechanisms determine that the identification and judgment of dual-use risks of biotechnology depend on the expert group from within the system, which may have some negative effects. For example, the internal standards and operational mechanisms within the scientific community may exclude the concerns, doubts and interventions of the government and the public. Even the judicial system, as a third party with traditional punitive capability, should rely on the judgment standards and operational systems established by the life science community in resolving legal disputes caused by the misuse of dual-use biotechnology.

Furthermore, biotechnology implementers who tend to be self-governing within the industry will resort to information asymmetry to deliberately resist the design of the public power system, which exacerbates the dual-use risks of biotechnology. Some biological scientists reject the top-down public power supervision system, which is most obvious in the field of synthetic biology research. Some technical experts in this field believe that supervision by public authorities can't keep up with the pace of technological change, and that the bottom-up industry self-regulation is superior to the traditional "hard law" in terms of time cost, and will be less likely to be resisted by practitioners [31]. However, bottom-up industry self-regulation, or other self-regulation modes, have failed to regulate the malicious abuse of the synthetic technology of known pathogenic viruses. It is also difficult for such self-regulation models to accommodate the greater risks caused by the creation of synthetic organisms based on standardized component methods. In addition, excessive reliance on industry self-regulation will easily lead to the public's misunderstanding of biotechnology development. Thus, the public may tend to believe that biotechnology development will undermine social consensus on biotechnology development and restrict the sustained and rapid progress of biotechnology if scientists assume certain technological risks after taking internal decisions to lift restrictions in some areas of research without having arrived and an informed consensus with the public. The public can do nothing except express doubt in the technology once such risks arise.

The He Jiankui incident of 2018 was an international controversy for two reasons. He violated institutional and international research regulations when he applied CRISPERCas9 gene editing technology to editing human embryos, and he conducted his experiments while claiming to be working on a cure for AIDS. As the public expects diseases to be cured and people to live longer, the internal private domain in life sciences will contradict public opinions on safety risk management and control. In a larger sense, different stakeholders have different understandings of and demands for the risks of dual-use biotechnology among biological scientists, social science experts, industries, media and the public.

2.2. Predicament 2: Top-Down Public Regulation often Lags behind Technological Iteration Due to Difficulty in the Prediction of Human-Made Risks of Dual-Use Biotechnology

It is difficult to predict the human-made risks of dual-use biotechnology before it has been used. According to Giddens, scientific and technological risk is a kind of "man-made risk" [32], and technology is neither good nor evil in itself. People use technology for good or evil purposes. Compared with the risk of public health and safety, the risk of biotechnological dual-use depends more on the intention and ability of its users. Therefore, 
the cause of biotechnology dual-use risk is stakeholders' behavior out of control under the comprehensive influence of both the internal and external environment.

While human beings are innovating dual-use biotechnology, they are endeavoring to modify the rules that should apply to it. However, since the human-made risks of dual-use biotechnology cannot be predicted, since it is easy to find loopholes in rules and policies, and since traditional "hard law" and other governance rules are slow to adjust, governance innovation cannot keep up with technology. The hope is that once governance rules are established, they will be able to keep pace with technological changes by establishing a system of adaptive governance for continuous technology evaluation. With the development of dual-use biotechnology and the deepening understanding of its risks, these methods usually require a cycle of data collection, evaluation and rule modification [33]. In other words, new scientific discoveries and knowledge in other fields must be applied to the iterative decision-making of the dual-use risk of biotechnology [34]. However, such governance innovation ideas tend to challenge the scientific formulation of risk governance.

In summary, the risk of information asymmetry of dual-use biotechnology has placed the traditional biotechnology industry self-governance model in trouble; at the same time, the difficulty of predicting the human-made risks of dual-use biotechnology leads to public regulation lagging behind technical iteration. The result is failed governance of dual-use risks of biotechnology. In the 1920s, Ogburn observed that as technology advanced, people's habits, thoughts and social arrangements fell behind, resulting in the decisive influence of technology on society [35]. The social reality since World War II has demonstrated that social harmony exists only in the minds of idealists. In contrast, heterogeneity is a basic feature of modern society. On this premise, the predicament of the management of dual-use risk of biotechnology reflects a failure in the checks and balances of the social governance structure. The risk governance rules cannot cover the blind spots of non-state actors and all biotechnology $\mathrm{R}$ and $\mathrm{D}$ and application scenarios. It is difficult for the system design mechanism to balance and coordinate the viewpoints and propositions in the life sciences and social sciences, in addition to finding a consensus among all parties. The balance between technology iteration and governance rules, and between private subjects' demands and social consensus is consequently lost.

\section{Governing Dual-Use Biotechnology Based on Experimentalist Governance Model}

\subsection{Experimentalist Governance Framework}

The risk of information asymmetry, the lack of knowledge of risks of abuse associated with research [36], and the unpredictability of human-made risks of dual-use biotechnology have caused a systematic dysfunction of "bottom-up" autonomy mode and "top-down" management-based regulation mode [37]. For these reasons, we cannot hope for a "one size fits all" solution.

To escape the predicament of dual-use biotechnology risk governance, it is necessary to re-examine current governance ideas and practices and propose targeted governance principles for existing problems, thus establishing a corresponding and specific governance mechanism. It is better to adopt the experimentalist governance mode, which includes "bottom up" and "top down" elements, to compensate for the limitations of different stakeholders (see Figure 1).

Experimentalist governance is a multi-layered mode of governance. It establishes an open-ended framework from the top and offers stakeholders in the field of dual-use biotechnology the freedom of discussion.

The goal of experimentalist governance is to reflect on and institutionalize policies in grassroots practice according to local conditions [38]. This approach could guide the country through policy uncertainties, assist in breaking the fetters of traditional authority and value norms, help practitioners remove the constraints of absolute interest and relative income distribution, optimize governance, and transform central organization departments from command-type to service-type $[39,40]$. 
In 2008, Sabel and Zeitlin first proposed experimentalist governance theory with the practice of EU governance under the recursive learning in decentralized compliance with international conventions $[41,42]$. Since then, experimentalist governance has been applied to global governance. Sandra and Tanya improved the dynamic structure in international society by relying on framework goals, reporting obligations, peer review and consultation processes [43]. This process included setting framework goals, letting the grassroots units implement those goals, regularly reporting and conducting peer evaluation, and periodically revising the framework.

In the view of the high uncertainty and potential implementation cost, Sabel and Victor institutionalized global experimentalist governance by setting of provisional goals under due process [44], which were then reviewed, revised, and promoted during implementation, and such experimentalist governance actions must rely on the robust support of governance mechanisms (for example, penalty defaults, which could promote joint action of public and private participants and increase the chances of success).

Global experimentalist governance has been extensively used in environmental issues. Among the most significant achievements of experimentalist governance are the Montreal Protocol [45,46], the Paris Agreement on Global Climate Change [44,47], the Climate and Clean Air Coalition to Reduce Short-Lived Climate Pollutants (CCAC) [48], the Forest Law Enforcement, Governance and Trade (FLEGT) [49], and the Global Food Safety Initiative [50].

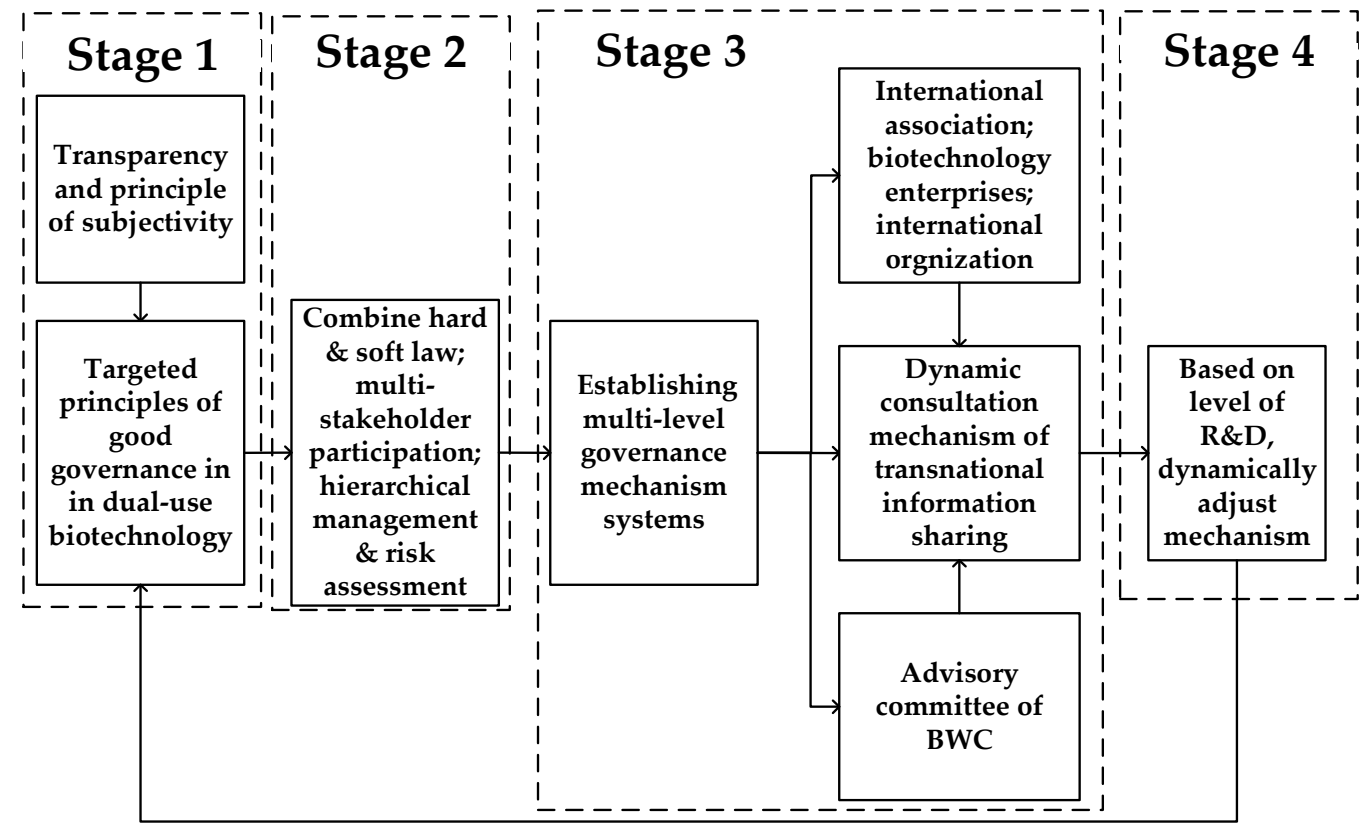

Figure 1. Global experimentalist governance model in governing dual-use biotechnology. Source: made by authors.

\subsection{Stage 1: Achieving Consensus on a General Global Governance Framework with Open-Ended Principles}

The first links of the experimental governance model is to invite as many stakeholders as possible to participate in the discussion, to construct an authoritative international platform for the discussion, to set an open-ended principle, and to form a legally binding agreement.

The Biological Weapons Convention of the United Nations is an open-ended model platform. It can establish communication among countries, and create opportunities for other non-state actors to participate in discussions through the mechanism of experts meetings, side events and best practice sharing in order to systematically monitor and review developments in science and technology. We believe that for the risk of dual-use biotechnology, all stakeholders need to reach a consensus on three principles: (1) risk communication, (2) process transparency, and (3) subjectivity. 
First, all States Parties should regard multi-party risk communication as the basic principle of governance. The National Research Council of the U.S. defines "risk communication" as an "interactive process in which individuals, groups, and institutions exchange information and ideas" [51]. Risk communication plays an important role in resolving conflicts caused by differing perceptions, as there is generally disagreement among the public, government officials, scientists and industries about the nature and severity of risks [52]. Under the media rendering of dual-use biotechnology in animal soldiers, genetic weapons, and super soldiers, the public become fearful of these artificial creatures as "unknown, frightening, uncontrollable, catastrophic and may affect future generations." Due to this bias, politicians and the public tend to pay more attention to the risk of bioterrorism than to other kinds of risks [53]. Therefore, it is essential to strengthen and extend contact and communication among biotechnologist, policy makers, social scientists and the public.

Second, it is also vital to strengthen the principle of transparent supervision throughout the process of life science research. It is important to monitor all dual-use biological testing activities that may increase the toxicity of biological agents or toxins or change the host range. All participants in research involving class I and II pathogenic microorganisms, biosafety level III or above laboratories, and vaccines and biological drugs production units, should be required to submit test contents, experiment implementation, contingency plans and other documents for approval before they conduct their scientific research. Those process could complete the supervision chain of "project initiation-review-approvalimplementation-verification", thus ensuring rigorous supervision of scientific research.

Third, systematic and sustained awareness-raising and education in biorisk management are crucial to building a culture of safe, secure and responsible research of dual-use biotechnology. The culture of safe, secure and responsible research emphasizes that enable effective awareness-raising of the security dimensions of life science research; promote research integrity and the responsible use of science; enhance accountability practices among practitioners; and foster access to emerging capabilities.

\subsection{Stage 2: Countries Take Actions Based on Local Conditions Led by the General Global Governance Framework}

Under the framework of the above-mentioned principles and objectives, the experimentalist governance model requires that grassroot practitioner should be provided with the power to act in accordance with local conditions. We believe that in view of the characteristics of dual-use biotechnology risks, different countries need to promote three aspects of work according to their actual conditions.

First, it is important to seek a dynamic balance between "hard law" and "soft law". Facing the dual-use risk of biotechnology, countries need to find a dynamic balance between "hard law" and "soft law". Soft law consists of democratic, open, universal and normative rules through the participation of stakeholders to regulate the social relations in biosafety governance, including its guidelines, codes, standards, and norms. It is therefore necessary to protect social and public interests, encourage scientific and technological research and industrial innovation, and ensure that the development of dual-use biotechnology is in accordance with the law and regulations. Due to the difficulty to meeting the demands for legal adjustment of new social contradictions caused by the dual-use risk of biotechnology by simply creating high legislative costs alone, and existence of complicated biological safety risks, no country has a panoramic understanding of the possible consequences of such risks, and some hidden dangers of such risks are far from being fully exposed. It will be increasingly difficult to supervise biotechnology as it gains momentum, as it is necessary to keep up with biotechnology through soft law, improving governance efficiency through "easily adjustable and easily controlled" mechanisms, and forming a policy reserve of national governance rules. Noticeably, integrating hard and soft law to create a prevention network needs a dynamic adjustment mechanism [54]. The most valuable, promising results of dual-use biotechnology are often produced in the early stage of research. Therefore, application of soft law, such as a code of conduct and professional rules, should initially 
predominate. As new technologies are being industrialized, regulation through hard law should be strengthened.

Second, to develop a dynamic consultant mechanism with multi-stakeholders in accordance with specific national conditions, the governance of emerging technologies should be the final outcome of interactions of socio-political management under the collective consultation of social actors [55]. This interactive mechanism should balance and coordinate the views and propositions between scientists and other stakeholders, thus deepening trust and integration. At the same time, biotechnologist can be encouraged to discuss issues such as social risk, which will be an important part of their scientific research activities in the future [56]. When such interactions produce a mutual understanding and shared vision, these biologists will form an "autonomous network" in which several entities and regulatory agencies will pool their social resources, intellectual expertise and interests [57]. With the advancement of dual-use biotechnology, this autonomous network must have the capability of dynamic learning and adaptive capacity. Multi-level organizations, including government regulatory departments, scientific research institutions, and industrial associations should carry out popularize science to improve the public understanding of dual-use biotechnology, enhancing enthusiasm for participating in and supervising the development of dual-use biotechnology. These activities can build public confidence in dual-use biotechnology and create a social environment more conducive to its sustained and healthy development. In short, government supervision should mobilize social forces, promote the orderly participation in the governance of the dual-use risk of biotechnology so that those social forces will jointly assume responsibility, formulate the rules, minimize risks and share in the outcome.

Third, to implement dynamic supervision of hierarchical management and risk assessment according to actual needs, each country should engage in hierarchical management and provide dynamic supervision mechanism for risk assessment. The idea of implementing hierarchical management of risks in the field of biosafety has become a common choice of major countries throughout the world yet have different characteristics. The "Biosafety Law of the People's Republic of China" of 2020, emphasizes that "the state implements classified management on biotechnology research and development activities," and that biotechnology research and development activities should be classified into high-, mediumand low-risk categories according to the amount of harm these activities may cause to public health, industry, agriculture, and the environment [58]. The "Dual-Use Research of Concern" (DURC), conducted by the National Science Advisory Board for Biosecurity (NSABB), focuses on 15 hazardous biological agents or toxins and seven types of partial dual-use research [2]. Furthermore, according to a country's own situation, it is necessary to develop risk assessment models by means of scenario analysis for policy makers to formulate and revise the laws and regulations [59,60]. In 2012, Bansak and Tucker proposed a $3 \times 3$ matrix model for risk assessment of dual-use biotechnology based on two key variables: abuse risk and controllability (Table 1). They then divided the abuse risk variables into four types: availability, vulnerability, potential hazard, and potential abuse crisis. The abuse risk can be high, medium, or low. Countries can modify the key variables of the model as needed.

\subsection{Stage 3: Dynamic Consultation Mechanism for Transnational Information Sharing and Action Review}

Based on the governance practices of countries tailored to local conditions, experimentalist governance requires that the multilateral platforms of international organizations need to further review and supervise the actions of the country, so as to realize the integration of "bottom-up" and "top-down" governance.

International organizations and other specialized associations need to review and supervise governments' implementation of the governance of dual-use biotechnology. We believe that to achieve effective review and supervision functions, international organizations need to establish a dynamic consultant mechanism for transnational information sharing, and ensure that the governance of international organizations and specialized 
associations is self-regulated and connected by legislation and regulatory policies of governments of various countries.

Under the current framework of international biotechnology security governance, the Biological Weapons Convention still has the most powerful binding force. Therefore, under the framework of the BWC, a scientific advisory committee of scientists from developed and developing countries that takes into account the interests of developed and underdeveloped countries should be established as soon as possible to conduct regular information tracking, risk research and evaluation, and information sharing so as to strengthen risk management of dual-use biotechnology worldwide. Each contracting party may formulate its own laws and regulatory policies according to the risk evaluation of dual-use biotechnology carried out by the Scientific Advisory Committee of the Biological Weapons Convention, based on the self-regulation established by international professional associations and other international organizations. Biologists and enterprises, as important objects of dual-use biotechnology governance, while joining international professional associations and other international organizations to constantly improve their self-regulation, have also achieved a dynamic negotiation process for governance subjects (see Figure 2).

Table 1. Risk assessment matrix of 14 emerging dual-use biotechnologies [61]. Source: Bansak \& Tucker. 2012.

\begin{tabular}{|c|c|c|c|c|}
\hline & & \multicolumn{3}{|c|}{ Controllability } \\
\hline & & Low & Medium & High \\
\hline \multirow{3}{*}{ Risk of abuse } & High & $\begin{array}{l}\text { DNA shuffling and } \\
\text { directed evolution }\end{array}$ & $\begin{array}{c}\text { Virus genome synthesis; } \\
\text { Combinatorial chemistry and high-throughput screening; } \\
\text { Development of psychoactive drugs }\end{array}$ & $\begin{array}{l}\text { Chemical micromachin- } \\
\text { ing equipment }\end{array}$ \\
\hline & Medium & $\begin{array}{l}\text { Immunoregulatory; } \\
\text { RNA interference }\end{array}$ & $\begin{array}{l}\text { Protein engineering; } \\
\text { Synthesis of peptide biological regulator }\end{array}$ & \\
\hline & Low & & $\begin{array}{l}\text { Standard component synthetic biology; } \\
\text { Personal genomics; } \\
\text { Gene therapy; } \\
\text { Aerosol vaccine }\end{array}$ & $\begin{array}{l}\text { Transcranial } \\
\text { magnetic stimulation }\end{array}$ \\
\hline
\end{tabular}

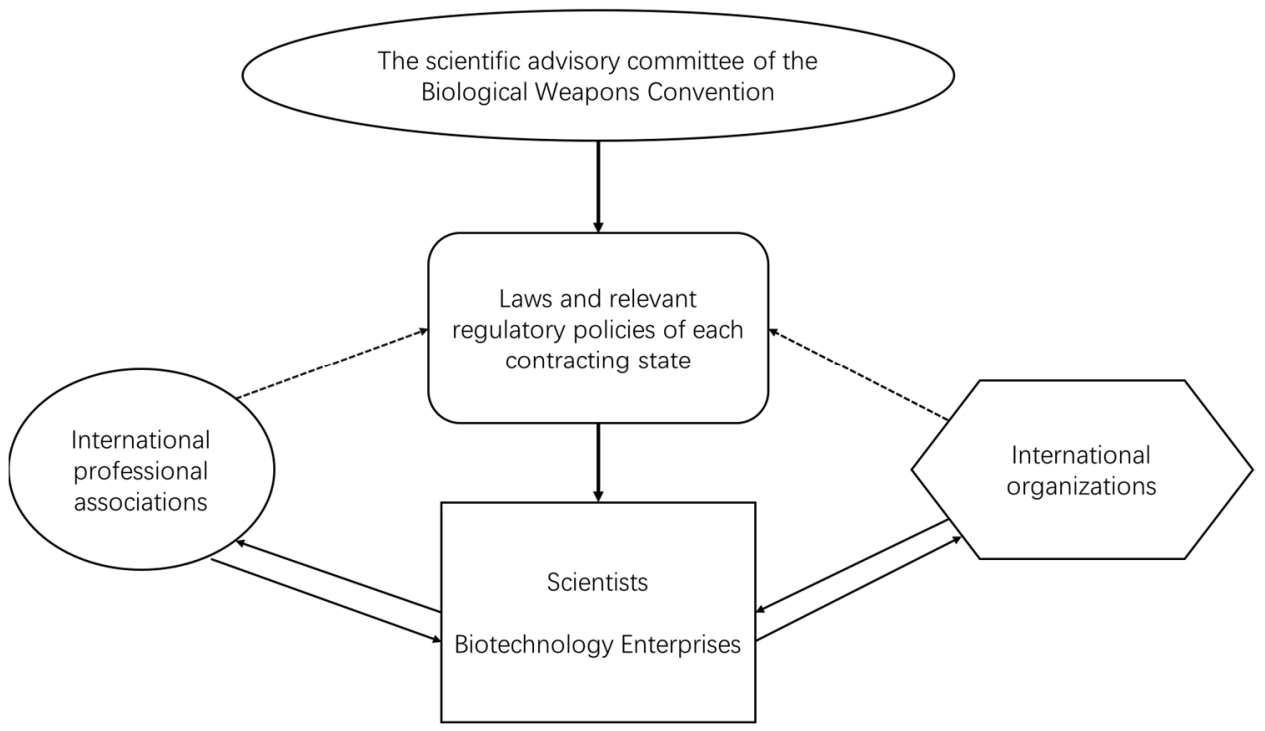

Figure 2. Dynamic negotiation mechanism of transnational information sharing. Source: made by authors.

\subsection{Stage 4: Evaluating and Adjusting Global Governance Framework}

On the basis of the three stages of reaching global consensus principles and goals, countries acting in accordance with local conditions, and reviewing and monitoring by international multilateral institutions, experimentalist governance will ultimately achieve the renewal and iteration of the global governance mechanism. 
Regarding the governance of dual-use biotechnology risks, it is necessary for international organizations to re-examine and update set principles and objectives as well as to strengthen and specify the key content under the circumstance of the continuous improvement of technology application and $\mathrm{R}$ and $\mathrm{D}$ level.

We believed that the global cooperation on risk management of dual-use biotechnology may benefit from a window of policy opportunities. The COVID-19 pandemic has drawn global attention to global health governance and biosafety, both of which are essential in forging a consensus on global governance. Despite the volatile international climate, many governments have prioritized responding to and solving the challenges in global governance. The Ninth Review Conference of the States Parties to the Biological Weapons Convention will be held in 2022, and a breakthrough in cooperation is possible. We call on the world to take advantage of this opportunity and allow biotechnology to benefit global development.

\section{Conclusions}

In the management of dual-use biotechnology risk, in addition to the predicament of technology iteration and governance rules caused by systematic internal attributes, the complex external environment has also exacerbated the contradiction between the demands of private subjects and social consensus. To this end, the experimental governance model could be a way of achieving good governance on dual-use biotechnology. The United Nations' "Living with Risk" proposal states that the risks facing human beings are the result of multiple environmental factors [62]. Thus, we must continue to develop dual-use biotechnology. At the same time, we need to adjust global governance strategy periodically to adapt to and meet the new requirement of sustainable development.

Author Contributions: Y.X., H.Y. and G.Q. developed the argument presented in this article. Conceptualization, Y.X. and H.Y.; Methodology, G.Q.; literature review, Y.X. and H.Y.; writing-original draft preparation, Y.X. and H.Y.; writing-review and editing, Y.X., H.Y. and G.Q.; supervision, Y.X.; project administration, H.Y. All authors have read and agreed to the published version of the manuscript.

Funding: National Social Science Fund of China: 20BFX163.

Conflicts of Interest: The authors declare no conflict of interest.

\section{References}

1. Alic, J.A.; Branscomb, L.M.; Brooks, H.; Carter, A.B.; Epstein, G. Beyond Spinoff: Military and Commercial Technologies in a Changing World; Harvard Business School Press: Boston, MA, USA, 1992; pp. 19-21.

2. National Science Advisory Board for Biosecurity. Enhancing Responsible Science Considerations for the Development and Dissemination of Codes of Conduct for Dual Use Research. 2010. Available online: https:/ / osp.od.nih.gov/biotechnology/ national-science-advisory-board-for-biosecurity-nsabb/\#reports_recommendations (accessed on 20 September 2021).

3. Tucker, J.B. The Decision Framework. In Innovation, Dual Use, and Security: Managing the Risks of Emerging Biological and Chemical Technologies; Tucker, J.B., Ed.; MIT Press: Cambridge, MA, USA, 2012; pp. 67-84.

4. National Science Advisory Board for Biosecurity. Proposed Framework for the Oversight of Dual Use Life Sciences Research: Strategies for Minimizing the Potential Misuse of Research Information; National Institutes of Health: Washington, DC, USA, 2007; pp. 3-5.

5. UNOG. Acquisition and Use of Biological and Toxin Weapons: Addressing the Threat. 2016. Available online: http://www.unog. ch/80256EDD006B8954/(httpAssets)/D8BAC3E78D302E91C125806700347BE8/\$file/BWCCONF.VIIIWP.19.pdf (accessed on 20 September 2021).

6. Maher, B. Bird-flu Research: The Biosecurity Oversight. Nature 2012, 485, 431-434. [CrossRef]

7. Imai, M.; Watanabe, T.; Hatta, M.; Das, S.C.; Ozawa, M.; Shinya, K.; Zhong, G.; Hanson, A.; Katsura, H.; Watanabe, S.; et al. Experimental adaptation of an influenza H5 HA confers. respiratory droplet transmission to a reassortant H5 HA/H1N1 virus in ferrets. Nature 2012, 486, 420-428. [CrossRef]

8. Garfinkle, M.; Knowles, L. Synthetic Biology, Biosecurity, and Biosafety; Sandler, R., Ed.; Ethics and Emerging Technologies; Northeastern University: Boston, MA, USA, 2014; pp. 533-534.

9. DiEuliis, D. Key National Security Questions for the Future of Synthetic Biology. Fletcher Forum World Aff. 2019, 43, 127-140.

10. Noyce, R.S.; Lederman, S.; Evans, D.H. Construction of an Infectious Horsepox Virus Vaccine from Chemically Synthesized DNA Fragments. PLoS ONE 2018, 13, e0188453. [CrossRef] 
11. Jackson, R.J.; Ramsay, A.J.; Beaton, C.S.; Hall, D.F.; Ramshaw, I.A. Expression of mouse interleukin-4 by a recombinant ectromelia virus suppresses cytotoxic lymphocyte responses and overcomes genetic resistance to mousepox. J. Virol. 2001, 75, 1205-1210. [CrossRef]

12. Esvelt, K.M.; Gemmell, N.J. Conservation Demands Safe Gene Drive. PLoS Biol. 2017, 15, e2003850. [CrossRef] [PubMed]

13. National Academies of Sciences, Engineering, and Medicine. Gene Drives on the Horizon: Advancing Science, Navigating Uncertainty, and Aligning Research with Public Values; National Academies Press: Washington, DC, USA, 2016; pp. 2-5.

14. Angela, B.; Stefan, E. Research ethics revised: The new CIOMS guidelines and the World Medical Association Declaration of Helsinki in context. Bioethics 2019, 33, 310-311.

15. Lentzos, F. Countering Misuse of Life Sciences through Regulatory Multiplicity. Sci. Public Policy 2008, 35, 55-164. [CrossRef]

16. China National Center for Biotechnology Development. Collection of Laws and Regulation of the People's Republic of China on Biosafety; Scientific and Technological Documentation Press: Beijing, China, 2019; p. 383.

17. National Research Council. Biotechnology Research in an Age of Terrorism; National Academies Press: Washington, DC, USA, 2004; pp. 16-17.

18. EU. Council Regulation (EC): Setting Up a Community Regime for the Control of Exports, Transfer, Brokering, and Transit of Dual-Use Items. Off. J. Eur. Union 2009, L 134/1, 428.

19. National Research Council. Challenges and Opportunities for Education about Dual Use Issues in the Life Sciences; National Academies Press: Washington, DC, USA, 2011; pp. 123-134.

20. Lei, W.; Tianxi, D.; Tiezhu, L. H5N1 BingduJiyin Gaizao ji Liangyong Shengwu jishu de Jinzhan yu Qishi. Rreport Int. Congr. Mil. Med. 2012, 121, 103.

21. NSABB. Framework for Conducting Risk and Benefit Assessments of Gain-of-Function Research, May 2007. Available online: https:/ / osp.od.nih.gov/wp-content/uploads/2015/09/NSABB_Framework_for_Risk_and_Benefit_Assessments_of_GOF_ Research-APPROVED.pdf (accessed on 17 September 2021).

22. National Academies of Sciences. Engineering, and Medicine, Biodefense in the Age of Synthetic Biology; National Academies Press: Washington, DC, USA, 2018; pp. 15-22.

23. Ministry of Science and Technology of the People's Republic of China. Measures for Safety Management of Biotechnology Research and Development, 25 July 2017. Available online: http://www.most.gov.cn/xxgk/xinxifenlei/fdzdgknr/fgzc/gfxwj/ gfxwj2017/201707/t20170725_134231.html (accessed on 18 September 2021).

24. United States of America. Article I: Reinforcing the Core Prohibition of the Biological Weapons Convention. 2016 BWC/CONF.VIII/WP.14. Available online: http://www.unog.ch/80256EDD006B8954/(httpAssets)/795621BBA4222B4 6C125805900417F36/\$file/BWCCONF.VIIIWP.14.pdf (accessed on 20 August 2021).

25. United Kingdom of Great Britain and Northern Ireland. Awareness-Raising, Education, Outreach: An Example of Best Practice. 2016. BWC/CONF.VIII/WP.10. Available online: http://www.unog.ch/80256EDD006B8954/(httpAssets)/266D6F5F0F7193F8 C125805200431081/\$file/BWC_CONF.VIII_WP.10.pdf (accessed on 21 August 2021).

26. United Kingdom of Great Britain. Review of Developments in Science and Technology: Key Points from the 2012-2015 Biological and Toxin Weapons Convention Intersessional Programme. 2016. BWC/CONF.VIII/WP.17. Available online: http://www. unog.ch/80256EDD006B8954/(httpAssets)/F903339F6A885942C125806100308FDD/\$file/BWCCONF.VIIIWP.17.pdf (accessed on 26 August 2021).

27. Germany. Strengthening Confidence-Building Measures in Regard to Dual Use Materials. 2016. BWC/CONF.VIII/PC/WP.35. Available online: http://www.unog.ch/80256EDD006B8954/(httpAssets)/6140863FD4B7D3F8C12580140051CB79/\$file/ BWCCONF.VIIIPCWP.35.pdf.-08-16 (accessed on 27 August 2021).

28. UNOG. Final Document of the Eighth Review Conference. 2017. BWC/CONF.VIII/4. Available online: https:/ /documents-ddsny.un.org/doc/UNDOC/GEN/G17/004/32/PDF/G1700432.pdf?OpenElement (accessed on 2 September 2021).

29. Yamaguchi, T.; Sato, H.; Kato-Itoh, M.; Goto, T.; Hara, H.; Sanbo, M.; Mizuno, N.; Kobayashi, T.; Yanagida, A.; Umino, A.; et al. Interspecies organogenesis generates autologous functional islets. Nature 2017, 542, 191-196. [CrossRef] [PubMed]

30. Garfinkel, M.; Endy, D.; Epstein, G.L.; Robert, M. Friedman, Synthetic Genomics: Options for Governance. Biosecur. Bioterror. Biodef. Strategy Pract. Sci. 2007, 5, 359-362. [CrossRef]

31. Maurer, S.M.; Zoloth, L. Synthesizing Biosecurity. Bull. At. Sci. 2007, 63, 16-18. [CrossRef]

32. Giddens, A. The Consequences of Modernity; He, T.; Ping, H., Translators; Yinlin Press: Nanjing, China, 2000 ; p. 12.

33. Mandel, G. Nanotechnology Governance. Ala. Law Rev. 2008, 59, 1379.

34. McCray, L.E.; Oye, K.A.; Petersen, A.C. Planned Adaptation in Risk Regulation: An Initial Survey of U.S. Environmental, Health, and Safety Regulation. Technol. Forecast. Soc. Chang. 2010, 77, 951-959. [CrossRef]

35. Volti, R. Society and Technological Change; Worth Publishers: New York, NY, USA, 2014; pp. 349-351.

36. Malcolm, R. Dando, Dual-Use Education for Life Scientists. Disarm. Forum 2009, 2, 41-44.

37. Sabel, C.F.; Simon, W.H. Minimalism and experimentalism in the administrative state. Geo. LJ 2011, 100, 53. [CrossRef]

38. De Búrca, G.; Keohane, R.O.; Sabel, C. Global experimentalist governance. Br. J. Political Sci. 2014, 44, 477-486. [CrossRef]

39. Ostrom, E. Governing the Commons: The Evolution of Institutions for Collective Action; Cambridge University Press: Cambridge, UK, 1990.

40. Abbott, K.W.; Green, J.F.; Keohane, R.O. Organizational ecology and institutional change in global governance. Int. Organ. 2016, 70, 247-277. [CrossRef] 
41. Sabel, C.F.; Zeitlin, J. Learning from difference: The new architecture of experimentalist governance in the EU. Eur. Law J. 2008, 14, 271-327. [CrossRef]

42. Sabel, C.F.; Zeitlin, J. Experimentalism in the EU: Common ground and persistent differences. Regul. Gov. 2012, 6, 410-426. [CrossRef]

43. Eckert, S.; Börzel, T.A. Experimentalist governance: An introduction. Regul. Gov. 2012, 6, 371-377. [CrossRef]

44. Sabel, C.F.; Victor, D.G. Governing global problems under uncertainty: Making bottom-up climate policy work. Clim. Chang. 2017, 144, 15-27. [CrossRef]

45. Wallack, J.S.; Ramanthan, V. The Other Climate Changers-Why Black Carbon and Ozone Also Matter. Foreign Aff. $2009,88,105$.

46. Hanzhi, Y. A new prescription for global public problems? Case study based on the Montreal Protocol. Remapping 2015, 4 288-300.

47. Burney, J.A.; Kennel, C.F.; Victor, D.G. Getting serious about the new realities of global climate change. Bull. At. Sci. 2013, 69, 49-57. [CrossRef]

48. Schmale, J.; Shindell, D.; von Schneidemesser, E.; Chabay, I.; Lawrence, M. Air pollution: Clean up our skies. Nat. News 2014, 515, 335. [CrossRef] [PubMed]

49. Overdevest, C.; Zeitlin, J. Experimentalism in transnational forest governance: Implementing european union forest law enforcement, governance and trade (FLEGT) voluntary partnership agreements in Indonesia and Ghana. Regul. Gov. 2018, 12, 64-87. [CrossRef]

50. Sabel, C.F.; Zeitlin, J. Experimentalism in transnational governance: Emergent pathways and diffusion mechanisms. GR EEN Work. Pap. 2011, 3. Available online: https://warwick.ac.uk/fac/soc/pais/research/csgr/green/papers/ experimentalismintransnationalgovernanceisapaper_2.pdf (accessed on 19 November 2021).

51. National Research Council. Committee on Risk Perception and Communication, Improving Risk Communication; National Academy: Washington, DC, USA, 1989; p. 2.

52. Mukunda, G.; Oye, K.A.; Mohr, S.C. What Rough Beast? Synthetic Biology, Uncertainty, and the Future of Biosecurity. Politics Life Sci. 2009, 28, 14-15. [CrossRef] [PubMed]

53. Stern, J. Dreaded Risk and the Control of Biological Weapons. Int. Secur. 2002, 3, 89-123. [CrossRef]

54. Littlewood, J. Managing the Biological Weapons Problem: From the Individual to the International. August 2004. Available online: http:/ / www.blixassociates.com/wp-content/uploads/2011/03/no14.pdf (accessed on 30 September 2021).

55. Rhodes, R.A.W. The New Governance: Governing without Government. Political Stud. 1996, 44, 657-660. [CrossRef]

56. Barben, D.; Fisher, E.; Selin, C.; Guston, D.H. Anticipatory Governance of Nanotechnology: Foresight, Engagement, and Integration. In The Handbook of Science and Technology Studies, 3rd ed.; Hackett, E.J., Amsterdamska, O., Lynch, M., Wajcman, J., Eds.; MIT Press: Cambridge, UK, 2007; pp. 979-1000.

57. Stoker, G. Governance as Theory: Five Proposition. Int. Soc. Sci. J. 1998, 50, 17-23. [CrossRef]

58. The National People's Congress of the People's Republic of China. Biosafety Law of the People's Republic of China. 2020. Available online: https:/ / flk.npc.gov.cn/detail2.html?ZmY4MDgwODE3NTI2NWRkNDAxNzUzZmFjYjEyYTEyNWQ\%3D (accessed on 25 September 2021).

59. Tucker, J.B. For case studies of historical incidents of bioterrorism. In Toxic Terror: Assessing Terrorist Use of Chemical and Biological Weapons; Tucker, J.B., Ed.; MIT Press: Cambridge, MA, USA, 2000; pp. 13-17.

60. Caruso, D. Synthetic Biology: An Overview and Recommendations for Anticipating and Addressing Emerging Risks; Center for American Progress Press: Washington, DC, USA, 2008; p. 10.

61. Bansak, K.C.; Tucker, J.B. Governance of Emerging Dual-Use Technologies. In Innovation, Dual Use, and Security: Managing the Risks of Emerging Biological and Chemical Technologies; Tucker, J.B., Ed.; MIT Press: Cambridge, MA, USA, 2012 ; pp. $305-339$.

62. United Nations Office Foe Disaster Risk Reduction. Living with Risk: A Global Review of Disaster Reduction Initiatives. June 2004. Available online: http:/ / www.unisdr.org/we/inform/publications/ 657 (accessed on 23 November 2021). 